\title{
The role of normative CSR promoting institutions in stimulating CSR disclosures in developing countries
}

\author{
Waris Ali \\ Bahauddin Zakariya University Sub-Campus Sahiwal, Farid Town, Sahiwal, Pakistan \\ Jedrzej George Frynas \\ Roehampton Business School, University of Roehampton, London, United Kingdom
}

Accepted for publication in:

Corporate Social Responsibility and Environmental Management

\begin{abstract}
This paper provides evidence that CSR forums and networks such as the UNGC local network, NGOs such as the WWF and CSR standards such as ISO14000 play a significant role in driving CSR disclosure, using data from publicly quoted companies in Pakistan. The role of CSR promoting institutions in enhancing capacity can provide a key explanation for the previously noted differences in disclosure patterns between developed and developing countries, on the one hand, and the improved disclosure in developing countries linked to the development of such institutions, on the other. Academically, this research demonstrates the vital importance of CSR promoting institutions, and the related normative isomorphism logics, for CSR disclosure in lower income countries, which have previously been assumed to largely lack such institutions. In practical terms, the significant relationship between CSR promoting institutions and CSR disclosure suggests that we need stronger policies to encourage the development of such institutions.
\end{abstract}

Keywords: Corporate Social Responsibility, CSR Promoting Institutions, CSR Disclosure, Quality of CSR Disclosure, Developing Country, Pakistan 


\section{Introduction}

CSR disclosure continues to attract considerable scholarly interest due to its variability across firms, industries or countries, its role as a social accountability mechanism, and the debate about factors influencing it (e.g. Parker, 2005; Owen, 2008; Gray, 2010; Mahadeo et al., 2011b). However, as the majority of the studies on factors influencing CSR disclosure were conducted in developed country contexts (cf. Fifka, 2013 meta-analysis of 200 studies), there is still much need for more research on factors influencing CSR disclosure in emerging/developing economies (see Ghazali, 2007; Belal \& Momin, 2009; Haji, 2013; Kansal et al., 2014). In particular, little is known about the interactions between 'CSR promoting institutions' and CSR disclosure in emerging/developing economies.

More research on developing countries is highly warranted given the perceived wide differences between developed and developing countries with regards to disclosure practices (Ali et al., 2017), which can be attributed to different socio-cultural environments, religious influences or levels of national economic development (Örtenblad, 2016; Jamali and Karam, 2017). Empirical studies in developed countries have pointed to a wide range of different influences - and hence a mixture of different domestic sources of isomorphic pressures - on CSR disclosure, emanating largely from domestic stakeholder groups - including regulators (Neu et al., 1998; Cormier \& Magnan, 1999; Chih et al., 2010; Shi et al., 2012), shareholders (see Neu et al., 1998; Toms, 2002; Thorne et al., 2014), creditors (Roberts, 1992; Oh et al., 2011), investors (Wilmshurst \& Frost, 2000), environmentalists (Deegan \& Gordon, 1996; Neu et al., 1998), the media (Neu et al., 1998; Deegan et al., 2002; Reverte, 2009; Nikolaeva \& Bicho, 2011) and the wider public (Belkaoui \& Karpik, 1989; Patten, 1991; Cormier et al., 2005). In contrast, scholars have assumed that corporations in developing countries perceive little pressure from the wider public and other domestic actors for CSR disclosure (see Belal \& Owen, 2007; Belal \& Cooper, 2011; Momin \& Parker, 2013). Consequently, empirical studies in developing countries have largely neglected to investigate the internal sources and normative influences on disclosure, instead pointing to the key influence of foreign stakeholder groups - and the associated coercive isomorphic pressures - on CSR disclosure, including most notably international buyers (see Belal \& Owen, 2007; Islam \& Deegan, 2008), foreign investors (Teoh \& Thong, 1984; Belal \& Owen, 2007; Khan et al., 2013; Chiu \& Wang, 2014), international media concerns (Islam \& Deegan, 2008) and international regulatory bodies such as the World Bank (see Rahaman et al., 2004)..

This paper helps to fill a gap in the literature by examining the role played by normative 'CSR promoting institutions' in stimulating the CSR reporting agenda in developing countries, given that previous studies have argued that a company will be more likely to act in a socially responsible manner if it there is a link between managers and normative institutions that promote responsible behaviour (Campbell, 2007; Fernandez-Feijoo et al., 2012; Blasco \& Zølner, 2010). Normative isomorphism can be the most potent form of institutional pressures with regards to organizational behaviour, as firms conform not because they perceive external actors to be powerful but because certain practices become embedded and "taken for granted as 'the way we do these things' " (Scott, 2001: 57) and, indeed, successful institutionalization of social and environmental disclosure within organizations in developed countries has been explained on the basis of "taken for granted" common systems of meaning, rules and routines (Contrafatto, 2014). Empirical research on developed countries has provided much evidence of the influence of such taken for granted normative influences on CSR disclosure, including from specific CSR promoting institutions (Brown et al., 2009a; Runhaar and Lafferty, 2009; Morhardt, 2009). In contrast, we know relatively little about the role of normative institutions that promote responsible behaviour in developing countries. Previous studies on the developing countries have pointed that the lack of CSR education and CSR reporting support are reasons 
for non-disclosure of CSR information (see Thompson \& Zakaria, 2004; Zulkifi \& Amran, 2006; Md \& Ibrahim, 2002). The companies' interaction with CSR promoting institutions might help them to overcome this weakness. Indeed a study conducted in Mexico showed a significant positive relationship between company interactions with an institution promoting responsible behaviour and the extent of CSR disclosure (Perez-Batrez et al., 2012). In other words, CSR promoting institutions may be an influential factor in explaining the reasons for disclosure and non-disclosure in developing countries. Therefore, this research sets out to examine the association between CSR promoting institutions and CSR disclosure made by companies operating in a developing country, specifically a lower income country which is said to lack many of the CSR promoting institutions (Thompson \& Zakaria, 2004; Zulkifi \& Amran, 2006; Lu \& Castka, 2009; Md \& Ibrahim, 2002; Perry \& Teng, 1999).

The disclosure studies conducted in developing countries predominantly focused on the amount of disclosures made when measuring CSR disclosure and paid little attention to the quality of CSR disclosure (see review by Belal \& Momin, 2009). Previous authors have pointed to the need to examine the quality of information disclosed when examining disclosures in developing countries (Belal et al., 2013). Therefore this research measures CSR disclosure by taking into account the quality of information disclosed and aims to examine the association between CSR promoting institutions and the quality of CSR disclosure. By investigating this research objective, this research contributes to the existing literature on developing countries by pointing to a significant positive relationship between CSR promoting institutions and CSR disclosures, measured in a qualitative way.

The remainder of this article is organised as follows. The next section defines CSR disclosure and reviews CSR disclosure literature on developing countries. The second section presents the theoretical framework for this study. The following section discusses the methodology for testing the theoretical model. The core of the paper consists of data analysis results of empirical tests. The penultimate section presents a discussion of the results and limitations of this study. The last section presents the conclusion.

\section{CSR Disclosure}

The term 'CSR disclosure' shares similarities with other concepts including 'corporate social reporting' (Gray et al., 1996) and 'social and environmental disclosure' (Hackston \& Milne, 1996; Gray et al., 1996) used sometimes interchangeably in the extant literature. CSR disclosure is defined as the voluntary provision of information on a corporation's interaction with its natural and social environment (Gray et al., 1996; Guthrie \& Parker, 1989; Deegan \& Gordon, 1996; Hackston \& Milne, 1996; O’Dwyer, 2002). The information published by a company may fall under several categories (Gray et al., 1996). However, most social accountancy researchers agree that CSR related information falls in the four categories: environment, human resource, products and consumer, and community involvement (Hackston \& Milne, 1996; Amran \& Devi, 2008; Branco \& Rodrigues, 2008). Therefore the information disclosed by a corporation in these categories will be considered as 'CSR disclosure' in this research. This may reveal how a corporation interacts with its employees, customers, environment, and the local community.

While sovereign governments have influenced 'CSR disclosure' in a number of countries including France (Knudsen et al., 2015) and China (Marquis \& Qian, 2014), CSR disclosure remains a largely unregulated phenomenon in most countries (Deegan \& Unerman, 2011). Due to the unregulated nature of CSR disclosures, managers have discretion about what and how to report. CSR disclosures may range from generalised disclosures on the one hand, to specific, quantitative and verifiable disclosures on the other hand (Hasseldine et al., 2005). Although 
the extant disclosure literature predominantly focused on examining the extent and level of CSR disclosure (Haniffa \& Cooke, 2005; Hasseldine et al., 2005; Branco \& Rodrigues, 2008; Mahadeo et al., 2011a), however, this research incorporates the nature of disclosures in accomplishing objectives of this research. The extant literature views the 'quality (nature) of CSR disclosure' as a proxy of a firm's actual social and environmental performance (Blowfield \& Murray, 2011).

Most previous studies on CSR disclosure in developing countries have largely focused on a small selection of emerging economies such as Malaysia, South Africa, Taiwan and India (see.g. Wanderley et al., 2008; Amran \& Devi, 2008; Haniffa \& Cooke, 2005; Huang \& Kuang, 2010; Singh \& Ahuja, 1983) and provided a largely descriptive account of CSR disclosure (e.g. Savage, 1994; Belal, 2001; Belal \& Momin, 2009; Sobhani et al., 2009; Mahadeo et al., 2011b). These studies have inter alia shown that companies in developing countries have paid more attention to human related themes as compared to community and environment related activities (e.g. Disu \& Gray, 1998; Belal, 2001; Gao et al., 2005; Haniffa \& Cooke, 2005; Ratanajongkol et al., 2006), while they paid considerably less attention to environmental related issues as compared to companies in developed countries (e.g. Belal \& Owen, 2007; Elijido-Ten, 2009; Sobhani et al., 2009). This scholarship pointed to very substantial differences is social and environmental disclosures among countries, which have typically been attributed to differences in the social, political, and governance contexts (e.g. Williams, 1999; Adams et al. 1998; Chih et al. 2010; Kamla, 2007; Wanderley et al., 2008), while other most commonly examined factors influencing CSR disclosure included corporate size, industry and corporate financial performance (Singh \& Ahuja, 1983; Haniffa \& Cooke, 2005; Tagesson et al., 2009).

Several studies on developing countries (i.e. Hong Kong, Malaysia, and Mauritius) have noted that the extent and level of CSR disclosure is increasing with the passage of time (Gao et al., 2005; Haniffa \& Cooke, 2005; Mahadeo et al., 2011b). However, this increase has typically been linked to external coercive pressures rather than normative pressures in the developing countries. The CSR reporting agenda in developing countries was typically ascribed to external forces/powerful stakeholders e.g. international buyers, foreign investors, international media, international regulatory bodies i.e. World Bank, and government regulations (see Rahaman et al. 2004; Amran \& Devi 2007; Belal \& Owen 2007; Islam \& Deegan 2008; Momin \& Parker 2013). Conversely, in contrast to developed countries, corporations in developing countries were said to perceive little pressure from the local public for CSR disclosure (see Belal \& Owen, 2007; Belal \& Cooper, 2011; Momin \& Parker, 2013) and internal factors such as the cost of reporting CSR information, non-availability of CSR data and a lack of motivation were said to hamper CSR disclosure in developing countries (Mitchell \& Hill 2009; De-Villiers 2003; Belal \& Cooper 2011; Momin \& Parker 2013). In other words, as previously indicated, disclosure studies have largely assumed away the internal sources and normative influences on disclosure, which presents an important gap in the literature.

\section{Theoretical Framework}

Institutional theory scholarship suggests that firms need to adapt their social and environmental practices in order to conform to the prevailing formal institutions (e.g. laws, policies or private agreements) and informal institutions (e.g. cultural norms, religious beliefs or professional routines) because they cannot survive without a certain level of external social approval (e.g. Barrena-Martínez, 2016; Jamali et al., 2017; cf. Frynas and Yamahaki, 2016). The theoretical model developed here is based on institutional theory and assumes that normative CSR promoting institutions may shape the CSR reporting agenda in developing countries in the 
same way as they demonstrably do in developed countries (see Perez-Batres et al., 2012; Deegan \& Blomquist, 2006). Scholarship from the institutional lens provides rich evidence that CSR reporting may be promoted by a range of institutions and different types of isomorphisms (recent examples from this journal include Gallén and Peraita, 2017; Gallego-Álvarez and Quina-Custodio, 2017), but - with reference to DiMaggio \& Powell's (1983) typology notable among them are normative pressures including from educational institutions, professional associations and social movement organizations (Levy \& Kolk, 2002; Muthuri \& Gilbert, 2011).

CSR promoting institutions such as CSR frameworks and networks, NGOs and CSR standard setting institutions are, according to institutional theory scholarship, considered to be among the normative institutions (Blasco \& Zølner, 2010; Muthuri \& Gilbert, 2011), which set the values and norms which define the appropriate behaviour of the firm. Values refer to "what is desirable/socially acceptable to pursue", while norms refer to "desirable ways of acting and being" (Bebbington et al., 2009, p.5). Marquis et al. (2007) further explained the norms and values of the society as rules of the game i.e. "what is right to do around here". These rules of the game are considered standards of appropriate corporate social behaviour. It has been strongly suggested in the literature that companies that interact with or are members of CSR promoting institutions will be more aware of CSR issues and will be more likely to act in a socially responsible manner (Campbell, 2007; Fernandez-Feijoo et al., 2012). In this study, we specifically investigate the influence of CSR frameworks and networks, NGOs, and CSR standard setting institutions, although it should be remembered that there are other normative institutions such as educational institutions, media, and civil society groups which can set the standards for appropriate corporate behaviour (Muthuri \& Gilbert, 2011). Specifically, we follow previous disclosure studies such as Perez-Batres et al. (2012), Deegan and Blomquist (2006) and Sumiani et al. (2007), which have shown that CSR reporting is shaped by CSR promoting institutions particularly CSR forums and networks, NGOs and standard setting institutions. Figure 1 presents a model of the hypothesized antecedents of CSR disclosure and the hypothesized relationships are described below.

[Insert Figure 1 here]

\section{CSR Forums and Networks}

Following institutional theory, professional networks are among the key sources of normative pressures, which can shape professionals' behaviour (DiMaggio \& Powell, 1983; Amran \& Devi, 2008). It has been observed that the presence of CSR forums and networks in developed (Fombrun, 2005; Jenkins, 2006; Mena \& Palazzo, 2012) and developing countries (see Belal \& Owen, 2007; Belal \& Cooper, 2011; Visser \& Tolhurst, 2010) encourages companies to address their associated social and environmental issues. Scholars have pointed out that CSR related forums and networks enable companies to understand, measure and to report CSR activities (Jenkins, 2009). Further to this, such forums and networks appear to influence companies to assume greater responsibility, transparency, accountability and better disclosure practices (Waddock, 2008; Steurer, 2010). 
Several CSR forums and networks (e.g. CSR Pakistan, CSRCP, UNGC, GCPLN ${ }^{1}$ etc.) operating in Pakistan are encouraging companies in Pakistan to act in a socially responsible manner and/or to disclose their CSR information, and many companies in Pakistan are members of these networks (Visser \& Tolhurst, 2010). In the light of institutional theory, due to companies' interaction with CSR forums and networks, normative isomorphism is likely to occur in those organizations through a process of professionalisation as a result of the increasing importance of highly specialist and complex professional CSR standards that are transmitted through CSR-related professional networks (Levy \& Kolk, 2002; Zelli \& van Asselt, 2013), which suggests that the normative type of institutions may change the behaviour of executives who interact with normative institutions. There are also some chances of mimetic isomorphism occurring, as pointed out by DiMaggio and Powell (1989), whereby companies imitate other companies' practices which are learned from professional networks and peers in order to look similar to other firms operating in the same institutional environment. The key role of professional networks in stimulating CSR activities has been noted by both academic and non-academic studies. These studies suggest that companies which are a member of professional networks, such as e.g. Sustainable Business Network and UNGC, are more likely to adopt social and environmental initiatives and exhibit better social and environmental performance (e.g. Cetindamar \& Husoy, 2007; Collins et al., 2007; McKinsey \& Company, 2004). With specific reference to CSR disclosure, some studies have suggested that professional networks can stimulate social and environmental reporting (e.g. Chen \& Bouvain, 2009; Perez-Batres et al., 2012; Tschopp \& Huefner, 2015). Perez-Batres et al. (2012) found that Mexican local companies which belonged to national sustainability programs were found to be significantly positively related to sustainability reporting, while Chen and Bouvain (2009) found that UNGC membership had a significant impact on disclosure, albeit this effect significantly differed by country and by issue. This scholarship suggests that corporate executives, members of professional bodies promoting responsible practices, may change their behaviour and disclose CSR information to conform to normative institutional actors' (i.e. CSR forums and networks here) expectations and therefore the following hypothesis can be derived:

H1. Companies which belong to CSR forums and networks (i.e. CSR Pakistan or CSRCP or UNGC or GCPLN) have a significant positive relationship with CSR disclosure.

\section{Non-Governmental Organizations (NGOs)}

According to institutional theory, NGOs are considered normative institutions (Amran \& Devi, 2008; DiMaggio \& Powell, 1983). NGOs played a significant role in highlighting companies' social and environmental issues in both developed (Tilt, 1994; Antal \& Sobczak, 2007; Baur \& Palazzo, 2011) and developing countries (Dogar, 2000; Eade \& Ligteringen, 2001; HussainKhaliq, 2004; Islam \& Deegan, 2008; Bano, 2008). NGOs along with business analysts and academic researchers have contributed considerably to the setting of social and environmental standards and to the development of social and environmental reporting frameworks such as the Global Reporting Initiative (GRI) guidelines (Westlund, 2008; Deegan \& Unerman, 2011). Academic studies have pointed out the role played by such NGOs in influencing corporate policies and practices related to labour and environmental issues (Tilt, 1994; Eade \&

${ }^{1}$ Corporate Social Responsibility Centre of Pakistan (CSRCP), United Nations Global Compact (UNGC), United Nations Global Compact Local Network (UNGCLN) 
Ligteringen 2001; Doh \& Guay, 2006; Antal \& Sobczak, 2007; Arenas et al., 2009; Lu \& Castka, 2009).

Several NGOs such as the International Labour Organization (ILO) and the World Wide Fund for Nature (WWF) operate in Pakistan, promoting the protection of labour rights and the environment (Eade \& Ligteringen 2001; Bano, 2008; Visser \& Tolhurst, 2010). Here we focus on the WWF, a global network which operates in more than 100 countries and creates awareness about issues such as climate change, the unsustainable use of natural resources and the vulnerability of rare species (WWF, 2013a). The WWF operates worldwide and is structured around a network of partly autonomous national offices. In Pakistan, 136 corporations are members of WWF-Pakistan (WWF, 2013b). With reference to institutional theory, the WWF may create normative pressures on the firms to incorporate environmental concerns into their business operations (Berman et al., 2003). Most pertinent to our study, various academic studies have argued that NGOs such as the WWF may create a pressure for corporations to disclose CSR related information (Bauer \& Fenn 1973; Heard \& Bolce 1981; Tilt, 1994; Aguilera et al., 2007; Islam \& Deegan, 2008; Brown et al., 2009; Bebbington et al., 2012). An academic study conducted in Australia has specifically shown that WWF initiatives (in this case, the evaluation of environmental reports of mining companies) have influenced the reporting behaviour of individual mining companies as well as revisions in the industry codes (Deegan \& Blomquist, 2006). Assuming that similar effects may exist in developing economies, we expect that companies which are members of WWF Pakistan will disclose more and better CSR information, particularly about the environment.

H2. Membership of an NGO (particularly WWF) has a significant positive relationship with CSR disclosure.

\section{CSR Standard Setting Institutions}

Following institutional theory, CSR standard-setting institutions are considered to be normative institutions, which can exert normative or mimetic pressure on the firm to adopt socially responsible practices (see Muthuri \& Gilbert, 2011). There are numerous CSR standards, for example SA 8000 for employee relations, ISO 14000 for environmental management, OHSAS 18001 for health and safety, AA1000S for stakeholders management, and IIP for employees' learning and development which encourage companies to improve their social and environmental performance (Fombrun, 2005). Every standard has specific requirements with regards to, for example, developing policy, establishing plans, implementing plans, evaluating performance, and reviewing plans to be fulfilled by the company to acquire a certification from the third party. By complying with such standard requirements, companies may be pushed towards better social and environmental performance. In fact, studies have inter alia suggested that corporations that interact with standard setting institutions are more likely to exhibit socially and environmentally responsible behaviour (Matten \& Moon, 2008; Dixon et al., 2005). The World Bank has shown that CSR labels and standards such as ISO14000, SA 8000, and AA 1000 have influenced CSR practices of multinational companies in both developed and developing countries (Berman et al., 2003). For example, some studies specifically showed that the adoption of certifications, in this case ISO 14000, results in better environmental performance (e.g. Heras-Saizarbitoria et al., 2011; Potoski \& Prakash, 2005). Similarly to this, a study conducted in Norway also showed that the adoption of ISO 9000 leads to an improvement in business performance in terms of reduction of bad products, decline in customer complaints, and increase in productivity and profitability (Sun, 2000).

Some certifications such as ISO 14000 and Eco-Management and Audit Scheme (EMAS) require corporations to disclose about their environmental performance (Reynolds \& Yuthas, 
2008). Indeed, a few studies conducted in a developing country context have specifically pointed to the influence of ISO certifications on social disclosure (Kuasirikun \& Sherer, 2004; Sumiani et al., 2007). Therefore, we expect that companies which adopt ISO certifications may disclose CSR information in order to conform to normative institutions' (i.e. ISO here) expectations. Thus, based on the above discussion, the following hypothesis can be derived:

H3. Companies that interact with CSR standards setting institutions have a significant positive relationship with CSR disclosure.

\section{Control variables}

The previous literature has shown a positive association between a company's size and CSR disclosure (Adams et al., 1998; Adams, 2002; Haniffa \& Cooke, 2002; Haniffa \& Cooke, 2005; Branco \& Rodrigues, 2008, Reverte, 2009; Mahadeo et al., 2011a). In addition to this, company profitability was also found to have a significant positive relationship with CSR disclosure (Haniffa \& Cooke, 2002; Thompson \& Zakaria, 2004). Furthermore, the industry's environmental sensitivity also appears to positively influence CSR disclosure (Reverte, 2009; Mahadeo et al., 2011a). Therefore, these variables are considered control variables in this research.

\section{Methodology}

\section{Research method}

This research uses a content analysis research method to codify the reported information in the annual reports into CSR disclosure themes (cf. Abbott \& Monsen, 1979; Milne \& Adler, 1999). It is a most commonly used method in the extant literature to determine corporate social and environmental disclosure scores (see Amran \& Devi, 2008; Bouten et al., 2011; Branco \& Rodrigues, 2008; Cormier et al., 2005; Deegan et al., 2002; Gray et al., 1995a; Gray et al., 1995b; Hackston \& Milne, 1996; Hou \& Reber, 2011; Monteiro \& Aibar-Guzmán, 2010; Zeghal \& Ahmed, 1990). Annual reports were selected as a source of information for content analysis due to their accessibility and credibility, in line with previous disclosure studies that utilised annual reports as a source of information for content analysis (see Amran \& Devi 2007; Belal 2001; Hackston \& Milne 1996; Haniffa \& Cooke 2005). This method allows for a comprehensive investigation of CSR disclosure by publicly quoted companies in our case study setting given that all of the listed companies of Pakistan are required to publish their CSR related information in annual reports as stipulated by CSR order, 2009.

\section{Sample}

The sample was drawn from listed companies of Pakistan, a low income developing country. The extant literature makes assumptions that particularly lower income countries such as Pakistan lack the CSR promoting institutions capable of widely encouraging CSR disclosure (Belal \& Owen, 2007; Jamali \& Neville, 2011; Lund-Thomsen et al., 2016), and we chose the Pakistani research setting precisely to further investigate this claim. 120 companies whose annual reports were available for the year 2011 on their respective websites or on the website of the Karachi Stock Exchange (KSE) were included in the sample. The makeup of the sample is provided in Table 1.

[Insert Table 1 here] 


\section{Measures}

\section{CSR disclosure quality}

The CSR disclosure instrument was developed based on previous studies (see Hackston \& Milne, 1996; Vountisjarvi, 2011; Branco \& Rodrigues, 2008) and later updated based on the CSR related information reported in the annual reports of thirty leading companies of Pakistan. The final CSR disclosure instrument consists of four dimensions e.g. environment, human resource, products and consumers, and community involvement, and each dimension has several themes. In total this disclosure instrument has 23 themes. As mentioned earlier, given that CSR disclosure is a multi-dimensional construct and consistent with the previous studies (Hackston \& Milne, 1996; Haniffa \& Cooke, 2005; Branco \& Rodrigues, 2008; Reverte, 2009), these dimensions have been combined in order to obtain a composite measure. In this study, the quality of CSR disclosure was examined by considering three types of information: aims, actions and performance indicators, reported about each CSR theme. The aims category covers companies' policies and general types of disclosure about a theme. The action category covers activities performed by a company to accomplish its aims/intentions. The performance category contains information about the inputs (e.g. amount and time spent on product developments etc.), the outputs (e.g. number of people benefited and number of new products introduced etc.) and the third party evidence (e.g. awards and survey results etc.) (see Vuontisjärvi, 2006; Bouten et al., 2011). Thus the aims and actions categories of a theme consist of declarative types of disclosure while the performance category of a theme covers both monetary and non-monetary quantitative evidence. The rank of a CSR disclosure theme was calculated based on the types of information (i.e. vision/goals, management approach, and performance indicators) disclosed about a theme. Table 2 explains the bases of a rank of each theme.

\section{[Insert Table 2 here]}

It is pertinent to mention that the score was assigned to a theme by manually reading the annual reports of companies included in the sample. Each annual report was coded by the two authors and later disparities were resolved through mutual consultation. The following formula was then used to calculate the CSR disclosure (quality) index:

$$
\text { CSRD (quality) Index }=1 / n\left(\sum_{i=1}^{n j} X i j\right)
$$

CSRD (quality) Index = Corporate Social Responsibility Disclosure (quality) Index

$\mathrm{Xij}=1-7$ was given to $\mathrm{i}^{\text {th }}$ theme of $\mathrm{j}^{\text {th }}$ firm based on the types of information disclosed about $\mathrm{i}^{\text {th }}$ theme

$\mathrm{Xij}=0$ if $\mathrm{i}^{\text {th }}$ theme of $\mathrm{j}^{\text {th }}$ firm was not disclosed

$n_{j} \leq 23$; number of themes expected for $j^{\text {th }}$ firm

\section{CSR promoting institutions variables}

CSR Forums and Networks (CSRF\&N): A dummy variable is used to measure companies' membership of CSR forums and networks. There are four major CSR networks: CSR Pakistan, CSRCP, United Nations Global Compact, and Global Compact Pakistan Local Network, which operate in Pakistan and provide assistance to companies in reporting their CSR activities. Membership of a CSR forum and network is considered to be a dichotomous variable in which 1 is assigned to a company that is a member of any of the CSR forums/networks and 0 
represents a company which is not a member of any CSR forum or network. This information can be traced from CSR forums/networks' websites.

NGOs (e.g. WWF): A dummy variable is used to represent the WWF, an NGO in which 1 is assigned to a firm which is a member of WWF and 0 is assigned to a firm which is not a member of WWF. This information can be extracted from the WWF website, which lists member companies.

CSR Standard Setting Institutions (CSRSSI): Standards related to employees and their health and safety, and standards related to products' quality and environment were used as a proxy for CSR standard setting institutions. This information is extracted from companies' annual reports. A dummy variable was used in which 1 was assigned to a company which has a CSR standard (such as SA8000, OHSAS, IIP or ISO14000) and 0 was assigned to a company which does not have these standards.

\section{Control variables}

Company size was measured by using total assets (see Haniffa \& Cooke, 2005; Mahadeo et al., 2011) and corporate profitability was measured by using return on assets (see Haniffa \& Cooke, 2005; Reverte, 2009). For environmental sensitivity, we used a dummy variable in which 1 was used for a company operating in an environmentally sensitive industry (SIC code 28XX excluding 283X, 22XX, 26XX, and 2911) and 0 if otherwise.

\section{Data Analysis Technique}

The relationship between CSR promoting institutions and CSR disclosures hypothesised earlier was tested by using multiple regression models. The general model of empirical analysis is as follows:

$$
\text { Disclosure }=f(\mathrm{CSR} \text { promoting institutions, Control variables })
$$

This general model can be further explained as:

Disclosure $=\alpha_{1}+\beta_{1} \mathrm{CSRF} \& \mathrm{~N}+\beta_{2} \mathrm{NGOs}+\beta_{3} \mathrm{CSRSSI}+\beta_{4} \mathrm{CS}+\beta_{5} \mathrm{CP}+\beta_{6} \mathrm{ES}+\varepsilon$

Here

CSRF\&N: CSR Forums and Networks

CSRSSI: CSR Standard Setting Institutions

CS: Company Size

CP: Corporate Profitability

ES: Environmental sensitivity

\section{Results}

\section{Descriptive Results}

Table 3 provides the results of a descriptive analysis of all the variables used in this study. In addition to this, it provides a test for normality for continuous variables. In terms of CSR disclosure (quality), the sampled companies got an average index score of 15.95. This indicates that the sampled companies paid attention to either limited CSR disclosure themes or made a disclosure about the aims and action indicators. Turning to the descriptive analysis of company characteristics, $35 \%$ of the sampled companies are operating in environmentally sensitive 
industries, $15 \%$ are members of CSR forums and networks, $16.7 \%$ are members of NGOs and $50.8 \%$ have ISO9000/ISO14000/SA 8000/OHSAS/IIP standards. In addition to this, companies included in the sample are large in size (average total asset $=$ PKR 36,296,792 thousands) and their average profitability is $3.11 \%$ of total assets (return on assets $=3.11 \%$ ).

\section{[Insert Table 3 here]}

\section{Regression Analysis Assumptions}

As mentioned earlier, a multivariate regression analysis technique was used to determine the relationship between different types of CSR promoting institutions and the quality of CSR disclosures. To obtain valid results, the four regression analysis assumptions i.e. normality, linearity, homoscedasticity, and non-multicollinearity were examined. The KolmogorovSmirnov test for normality shows that scale variables included in the model are not normal (see Table 3). To remove the elements of non-normality, we applied natural log and van der Waerden's normal score transformation mentioned against those variables (see Table 3). The plot of standardized predicted values against the studentized residuals does not exhibit any nonlinear pattern in the overall model. Further the residuals plot shows that the residuals are equally dispersed below and above the central line. It shows evidence of homoscedasticity of the residuals. To check Multicollinearity among the independent variables, various measures including correlations (highest correction between any two independent variable is .442), tolerance value (ranges 0.674 - .915), and variance inflation factor (ranges 1.483 - 1.093) were calculated (see Table $4 \& 5$ ) showing that multicollinearity among the independent variables is not an issue.

\section{[Insert Tables 4-5 here]}

\section{Regression analysis results}

This research has used OLS regression analysis to determine the effect of independent variables on the dependent variables (see Table 5). As a base model, Model 1 contains all of the control variables and control variables collectively explain $33 \%$ (adjusted $\mathrm{R}^{2}$ ) of the overall variation in the quality of CSR disclosure $(\mathrm{P}<0.001)$. The results show that firm size $(\mathrm{p}<0.001)$ and company profitability $(\mathrm{P}<0.05)$ have a significant positive relationship with the quality of CSR disclosure. This is consistent with the existing environmental disclosure studies conducted in the developed countries showing a significant positive relationship of company size and company profitability with the quality of environmental disclosure (France: Cormier \& Magnan, 2003; Germany: Cormier et al., 2005). These results suggest that large and highly profitable companies appear to make 'high quality' disclosure about CSR related issues. Environmental sensitivity control variable also has a significant positive relationship with the quality of CSR disclosure. It suggests that environmentally sensitive companies in Pakistan appear to make higher quality disclosures about social and environmental issues.

Model 2 contains all the experimental variables and these variables collectively explain $38.9 \%$ (adjusted $\mathrm{R}^{2}$ ) of the overall variation in the quality of CSR disclosure $(\mathrm{P}<0.001)$. The result shows that all the experimental variables: CSR forums and networks $(\mathrm{P}<0.001)$, member of NGOs $(\mathrm{P}<0.10)$ and CSR standard setting institutions $(\mathrm{P}<0.001)$ have a significant positive relationship with the quality of CSR disclosure. The results show that CSR forums and networks and CSR standard setting institutions play a strong role in driving CSR quality reporting agenda, while there is only weak evidence for the role of NGOs in promoting the quality of CSR reporting.

Model 3 combines all of the control and experimental variables and these variables collectively explain $47.4 \%$ (adjusted $\mathrm{R}^{2}$ ) of the overall variance in quality of CSR reporting $(\mathrm{P}<0.001)$ and also shows a significant increase in overall explanatory power of control (Adjusted $\mathrm{R}^{2} 33 \%$ ) 
and experimental variables (adjusted $\mathrm{R}^{2} 38.9 \%$ ). The results show that CSR forums and networks $(\mathrm{P}<0.001)$, membership of NGOs $(\mathrm{P}<0.10)$ and CSR standards setting institutions $(\mathrm{P}<0.001)$ have a significant positive relationship with the quality CSR disclosure and thus provide support for $\mathrm{H}_{1}, \mathrm{H}_{2}$, and $\mathrm{H}_{3}$ respectively. In other words, these results show, as expected, that there is a significant positive relationship between membership of CSR forums and networks $\left(\mathrm{H}_{1}\right)$, CSR standards setting institutions $\left(\mathrm{H}_{2}\right)$, and membership of NGOs $\left(\mathrm{H}_{3}\right)$ with the quality of CSR disclosure. Among the control variables, company size, company profitability and environmental sensitivity were all found to be significant.

\section{Discussion and Conclusions}

The primary motive for this study was to investigate the role played by CSR promoting institutions in promoting the CSR agenda, specifically CSR disclosure, in developing countries. This research has provided strong evidence that CSR forums and networks such as the UNGC local network, NGOs such as the WWF and CSR standards such as ISO14000 have played a significant positive role in driving CSR disclosure in at least one low income developing country. Thus, this research contributes to the literature on the determinants of CSR disclosure by demonstrating that CSR promoting institutions can play an important role in encouraging CSR disclosure even in low income countries that are beset by internal civil conflict and ostensibly lack effective state institutions.

While previous studies have often argued that the CSR disclosure agenda in developing countries can be implemented through formal regulation only (e.g. Boden, 1999; Jacobs \& Kemp, 2002), our findings advance the research on social and environmental disclosure in developing countries by emphasizing the key normative roles of CSR promoting institutions in stimulating CSR reporting in these countries. In line with previous scholarly arguments that a company will be more likely to act in a socially responsible manner if there is a link between managers and normative institutions that promote responsible behaviour (Campbell, 2007; Fernandez-Feijoo et al., 2012), we found that companies adapt their disclosure practices to the prevailing normative standards (e.g. protecting animal species and the natural environment, and expectations of philanthropy) that emanate from interactions with CSR networks, NGOs or CSR standards.

Previous studies on developing countries, most notably on neighbouring and culturally close Bangladesh, have asserted that developing country companies are prevented from effectively disclosing their CSR performance due to the lack of specific knowledge or training for embarking on CSR reporting initiatives - i.e. poor social and environmental disclosure was said to be related to the lack of capacity (Belal \& Owen, 2007; Belal \& Cooper, 2011). In this context, specific CSR promoting institutions can help overcome these shortcomings and assist capacity building in developing countries. In other words, the interactions between companies and CSR promoting institutions in a developing country like Pakistan might have helped these companies to gain the expertise required for the effective disclosure of CSR performance. The role of CSR promoting institutions in enhancing capacity can provide a key explanation for the previously noted differences in disclosure patterns between developed and developing countries, on the one hand, and the improved disclosure in developing countries linked to the development of such institutions, on the other. In general terms, our findings direct attention to the importance of increasingly highly specialist and complex professional standards within the field of accounting (e.g. Rodrigues and Craig 2007; Brandau et al. 2013), which increasingly requires specialist professional institutions with their own normative isomorphism logics. 
In practical terms, the significant relationship between CSR promoting institutions and CSR disclosure suggests that there is a need for policies to encourage the creation and promotion of such institutions, which may help to supplement state institutions. Given the empirical evidence from developed countries on the crucial influence of a variety of non-state institutions on CSR disclosure, it is unlikely that CSR disclosure in developing countries could be effectively developed through the exclusive reliance on state regulations and institutions alone. Mandatory CSR disclosure in countries such as India, Indonesia and South Africa has reportedly helped to significantly improve the extent of CSR disclosure (KPMG 2015), but CSR promoting institutions may be better placed to help improve the quality of CSR disclosure through normative expectations of higher reporting standards.

This research is subject to a number of limitations. Firstly, this research used CSR disclosure score as a composite measure rather than treating dimensions of CSR separately in the regression models. Future researchers may incorporate different dimensions of CSR while examining the relationship between CSR promoting institutions and CSR disclosure. Secondly, empirical tests were performed on large listed companies of Pakistan which may limit generalizability of the research findings. Future researchers should incorporate non-listed companies to further validate these findings. Future research may also examine the influence of other normative institutions (e.g. educational institutions) on CSR disclosure to supplement the findings of this research. Nonetheless, our study advances knowledge about the determinants of CSR disclosure in developing economies by pointing to the role of normative CSR promoting institutions in disclosure, in contrast to previous studies that focused on coercive pressures, particularly emanating from foreign buyers and investors. Given the remarkable recent rise of CSR disclosure among companies from emerging and developing countries (KPMG, 2013 and 2015), future researchers should discover the normative predictors of a firm's propensity to engage in disclosure in developing countries. We believe that, by incorporating different types of CSR promoting institutions, researchers will be able to paint a much fuller picture of the determinants of CSR disclosure in emerging and developing economies.

\section{References}

Abbott WF, Monsen RJ. 1979. On the measurement of corporate social responsibility: Selfreported disclosures as a method of measuring corporate social involvement. Academy of Management Journal 22(3): 501-515.

Adams CA. 2002. Internal organisational factors influencing corporate social and ethical reporting: Beyond current theorising. Accounting, Auditing \& Accountability Journal 15(2): 223-250.

Adams CA, Hill W, Roberts CB. 1998. Corporate social reporting practices in Western Europe: Legitimating corporate behaviour? British Accounting Review 30(1): 1-21.

Aguilera RV, Rupp DE, Williams CA, Ganapathi J. 2007. Putting the S back in corporate social responsibility: A multilevel theory of social change in organizations. Academy of Management Review 32(3): 836-863.

Ali W, Frynas JG, Mahmood Z. 2017. Determinants of Corporate Social Responsibility (CSR) Disclosure in developed and developing countries: A literature review. Corporate Social Responsibility and Environmental Management, DOI: 10.1002/csr.1410.

Amran A, Devi SS. 2007. Corporate social reporting in Malaysia: A political theory perspective. Malaysian Accounting Review 6(1): 19-44. 
Amran A, Devi SS. 2008. The impact of government and foreign affiliate influence on corporate social reporting: The case of Malaysia. Managerial Auditing Journal 23(4): 386404.

Antal AB, Sobczak A. 2007. Corporate social responsibility in France: A mix of national traditions and international influences. Business \& Society 46(1): 9-32.

Arenas D, Lozano JM, Albareda L. 2009. The Role of NGOs in CSR: Mutual Perceptions among Stakeholders. Journal of Business Ethics 88 (1): 175-197.

Bano M. 2008. Dangerous correlations: aid's impact on NGOs' performance and ability to mobilize members in Pakistan. World Development 36(11): 2297-2313.

Barrena-Martínez J, Lopez-Fernandez M, Romero-Fernández PM. 2016. Corporate social responsibility: Evolution through institutional and stakeholder perspectives. European Journal of Management and Business Economics 25(1): 8-14.

Bauer RA, Fenn DH. 1973. What is a corporate social audit? Harvard Business Review 51(1): 37-48.

Baur D, Palazzo G. 2011. The moral legitimacy of NGOs as partners of corporations. Business Ethics Quarterly 21(4): 579-604.

Bebbington J, Higgins C, Frame B. 2009. Initiating sustainable development reporting: Evidence from New Zealand. Accounting, Auditing \& Accountability Journal 22(4): 588625.

Bebbington J, Kirk EA, Larrinaga C. 2012. The production of normativity: A comparison of reporting regimes in Spain and the UK. Accounting, Organizations and Society 37(2): 7894.

Belal AR. 2001. A study of corporate social disclosures in Bangladesh. Managerial Auditing Journal 16(5): 274-289.

Belal AR, Cooper S. 2011. The absence of corporate social responsibility reporting in Bangladesh. Critical Perspectives on Accounting 22(7): 654-667.

Belal AR, Momin M. 2009. Corporate social reporting (CSR) in emerging economies: A review and future direction. Research in accounting in emerging economies 9(1): 119-143.

Belal AR, Owen DL. 2007. The views of corporate managers on the current state of, and future prospects for, social reporting in Bangladesh: An engagement-based study. Accounting, Auditing \& Accountability Journal 20(3): 472-494.

Belal AR, Cooper SM, Roberts RW. 2013. Vulnerable and exploitable: The need for organisational accountability and transparency in emerging and less developed economies. Accounting Forum 37(2): 81-91.

Belkaoui A, Karpik GP. 1989. Determinants of the corporate decision to disclose social information. Accounting, Auditing \& Accountability Journal 2(1): 36-51.

Berman J E, Webb T, Fraser DJ, Harvey PJ, Barsky J, Haider A, ... Williams I. 2003. Race to the Top: Attracting and Enabling Global Sustainable Business, Business Survey Report. World Bank Group, October 2003.

Blasco M, Zølner M. 2010. Corporate social responsibility in Mexico and France: exploring the role of normative institutions. Business \& Society 49(2): 216-251.

Blowfield M, Murray A. 2011. Corporate responsibility (2nd ed.). Oxford: Oxford University Press. 
Boden R. 1999. Figure it out yourself: financial reporting, accountability and the selfemployed. Critical Perspectives on Accounting 10(1): 37-62.

Bouten L, Everaert P, van Liedekerke L, De Moor L, Christiaens J. 2011. Corporate social responsibility reporting: A comprehensive picture? Accounting Forum 35(3): 187-204.

Branco MC, Rodrigues LL. 2008. Factors influencing social responsibility disclosure by Portuguese companies. Journal of Business Ethics 83(4): 685-701.

Brandau M, Endenich C, Trapp R, Hoffjan A. 2013. Institutional drivers of conformity Evidence for management accounting from Brazil and Germany. International Business Review 22(2): 466-479.

Brown HS, De Jong M, Lessidrenska T. 2009. The rise of the Global Reporting Initiative: a case of institutional entrepreneurship. Environmental Politics 18(2): 182-200.

Brown HS, De Jong M, \& Levy DL. 2009a. Building institutions based on information disclosure: lessons from GRI's sustainability reporting. Journal of Cleaner Production 17(6): 571-580.

Campbell JL. 2007. Why would corporations behave in socially responsible ways? An institutional theory of corporate social responsibility. Academy of Management Review 32(3): 946-967.

Cetindamar D, Husoy K. 2007. Corporate social responsibility practices and environmentally responsible behavior: The case of the United Nations Global Compact. Journal of Business Ethics 76(2): 163-176.

Chen S, Bouvain P. 2009. Is Corporate Responsibility Converging? A Comparison of Corporate Responsibility Reporting in the USA, UK, Australia, and Germany. Journal of Business Ethics 87(1): 299-317.

Chih HL, Chih HH, Chen TY. 2010. On the determinants of corporate social responsibility: International evidence on the financial industry. Journal of Business Ethics 93(1): 115-135.

Chiu T, Wang Y. 2014. Determinants of social disclosure quality in Taiwan: An application of stakeholder theory. Journal of Business Ethics 121(1): 1-20.

Collins E, Lawrence S, Pavlovich K., Ryan C. 2007. Business networks and the uptake of sustainability practices: the case of New Zealand. Journal of Cleaner Production 15(8): 729-740.

Contrafatto M. 2014. The institutionalization of social and environmental reporting: An Italian narrative. Accounting, Organizations and Society 39(6): 414-432.

Cormier D, Magnan M. 1999. Corporate environmental disclosure strategies: Determinants, costs and benefits. Journal of Accounting, Auditing \& Finance 14(4): 429-451.

Cormier D, Magnan M. 2003. Environmental reporting management: A continental European perspective. Journal of Accounting \& Public Policy 22(1): 43-62.

Cormier D, Magnan M, van Velthoven B. 2005. Environmental disclosure quality in large German companies: Economic incentives, public pressures or institutional conditions? European Accounting Review 14(1): 3-39.

De Villiers CJ. 2003. Why do South African companies not report more environmental information when managers are so positive about this kind of reporting?. Meditari Accountancy Research 11(1): 11-23. 
Deegan C, Blomquist C. 2006. Stakeholder influence on corporate reporting: An exploration of the interaction between WWF-Australia and the Australian minerals industry. Accounting, Organizations and Society 31(4): 343-372.

Deegan C, Gordon B. 1996. A study of the environmental disclosure practices of Australian corporations. Accounting and Business Research 26(3): 187-199.

Deegan C, Unerman J. 2011. Financial accounting theory (2nd ed.). London: McGraw-Hill.

Deegan C, Rankin M, Tobin J. 2002. An examination of the corporate social and environmental disclosures of BHP from 1983-1997: A test of legitimacy theory. Accounting, Auditing \& Accountability Journal 15(3): 312-343.

DiMaggio PJ, Powell WW. 1983. The iron cage revisited: Institutional isomorphism and collective rationality in organizational fields. American Sociological Review 48(2): 147160.

Disu A, Gray RH. 1998. An exploration of social reporting and MNCs in Nigeria. Social and Environmental Accounting 18(2): 13-15.

Dixon R, Mousa GA, Woodhead A. 2005. The role of environmental initiatives in encouraging companies to engage in environmental reporting. European Management Journal 23(6): 702-716.

Dogar N. 2000. Workplace monitoring as a tool for combating child labour: Experience in Pakistan. ILO/Japan Asian Regional Meeting on Monitoring Child Labour at the Workplace Dhaka, Bangladesh, ILO Technical Paper (2): 1-14.

Doh JP, Guay TR. 2006. Corporate social responsibility, public policy, and NGO activism in Europe and the United States: An Institutional-Stakeholder perspective. Journal of Management Studies 43(1): 47-73.

Eade D, Ligteringen E. 2001. Debating Development NGOs and the Future: Essays from Development in Practice. Great Britain: Oxfam International.

Elijido-Ten E. 2009. Can stakeholder theory add to our understanding of Malaysian environmental reporting attitudes? Malaysian Accounting Review 8(2): 85-110.

Fernandez-Feijoo B, Romero S, Ruiz S. 2012. Does board gender composition affect corporate social responsibility reporting? International Journal of Business and Social Science 3(1): 31-38.

Fifka MS. 2013. Corporate Responsibility Reporting and its Determinants in Comparative Perspective-a Review of the Empirical Literature and a Meta-analysis. Business strategy and the environment 22(1): 1-35.

Fombrun CJ. 2005. Building corporate reputation through CSR initiatives: Evolving standards. Corporate Reputation Review 8(1): 7-11.

Frynas JG, Yamahaki C. 2016. Corporate social responsibility: Review and roadmap of theoretical perspectives. Business Ethics: A European Review 25(3): 258-285.

Gallego-Álvarez I, Quina-Custodio IA. 2017. Corporate Social Responsibility reporting and Varieties of Capitalism: an international analysis of state-led and liberal market economies. Corporate Social Responsibility and Environmental Management, DOI: 10.1002/csr.1421.

Gallén ML, Peraita C. 2017. The relationship between femininity and sustainability reporting. Corporate Social Responsibility and Environmental Management, DOI: 10.1002/csr.1423. 
Gao SS, Heravi S, Xiao J.Z. 2005. Determinants of corporate social and environmental reporting in Hong Kong: A research note. Accounting Forum 29(2): 233-242.

Ghazali NA. 2007. Ownership structure and corporate social responsibility disclosure: Some Malaysian evidence. Corporate Governance 7(3): 251-266.

Gray R. 2010. A re-evaluation of social, environmental and sustainability accounting: an exploration of an emerging trans-disciplinary field? Sustainability Accounting, Management and Policy Journal 1(1): 11-32.

Gray R, Kouhy R, Lavers S. 1995a. Corporate social and environmental reporting: A review of the literature and a longitudinal study of UK disclosure. Accounting, Auditing \& Accountability Journal 8(2): 47-77.

Gray R, Kouhy R, Lavers S. 1995b. Constructing a research database of social and environmental reporting by UK companies. Accounting, Auditing \& Accountability Journal 8(2): 78-101.

Gray R, Owen D, Adams C. 1996. Accounting \& Accountability: Changes and Challenges in Corporate and Environmental Reporting. Hemel Hempstead: Prentice Hall.

Guthrie J, Parker LD. 1989. Corporate social reporting: A rebuttal of legitimacy theory. Accounting \& Business Research 19(76): 343-352.

Hackston D, Milne MJ. 1996. Some determinants of social and environmental disclosures in New Zealand companies. Accounting, Auditing \& Accountability Journal 9(1): 77-108.

Haji AA. 2013. Corporate social responsibility disclosures over time: Evidence from Malaysia. Managerial Auditing Journal 28(7): 647-676.

Haniffa RM, Cooke TE. 2002. Culture, corporate governance and disclosure in Malaysian corporations. Abacus 38(3): 317-349.

Haniffa RM, Cooke TE. 2005. The impact of culture and governance on corporate social reporting. Journal of Accounting \& Public Policy 24(5): 391-430.

Hasseldine J, Salama AI, Toms JS. 2005. Quantity versus quality: The impact of environmental disclosures on the reputations of UK Plcs. British Accounting Review 37(2): 231-248.

Heard JE, Bolce WJ. 1981. The political significance of corporate social reporting in the United States of America. Accounting, Organizations and Society 6(3): 247-254.

Heras-Saizarbitoria I, Molina-Azorín JF, Dick GP. 2011. ISO 14001 certification and financial performance: selection-effect versus treatment-effect. Journal of Cleaner Production 19(1): 1-12.

Hou J, Reber BH. 2011. Dimensions of disclosures: Corporate social responsibility (CSR) reporting by media companies. Public Relations Review 37(2): 166-168.

Huang C, Kung F. 2010. Drivers of environmental disclosure and stakeholder expectation: Evidence from Taiwan. Journal of Business Ethics 96(3): 435-451.

Hussain-Khaliq S. 2004. Eliminating child labour from the Sialkot soccer ball industry. Journal of Corporate Citizenship 13(1): 101-107.

Islam MA, Deegan C. 2008. Motivations for an organisation within a developing country to report social responsibility information. Accounting, Auditing \& Accountability Journal 21(6): 850-874. 
Jacobs K, Kemp J. 2002. Exploring accounting presence and absence: case studies from Bangladesh. Accounting, Auditing \& Accountability Journal 15(2): 143-161.

Jamali D, Karam C. 2017. Corporate social responsibility in developing countries as an emerging field of study. International Journal of Management Reviews, DOI: 10.1111/ijmr.12112.

Jamali D, Neville B. 2011. Convergence versus divergence of CSR in developing countries: An embedded multi-layered institutional lens. Journal of Business Ethics 102(4): 599-621.

Jamali D, Lund-Thomsen P, Khara N. 2017. CSR institutionalized myths in developing countries: An imminent threat of selective decoupling. Business \& Society 56(3): 454-486.

Jenkins H. 2006. Small business champions for corporate social responsibility. Journal of Business Ethics 67(3): 241-256.

Jenkins H. 2009. A 'business opportunity' model of corporate social responsibility for smalland medium-sized enterprises. Business ethics: A European review 18(1): 21-36.

Kamla R. 2007. Critically Appreciating Social Accounting and Reporting in the Arab Middle East: A Postcolonial Perspective. Advances in International Accounting 20(1): 105-177.

Kansal M, Joshi M, Batra GS. 2014. Determinants of corporate social responsibility disclosures: Evidence from India. Advances in Accounting 30(1): 217-229.

Khan A, Muttakin MB, Siddiqui J. 2013. Corporate governance and corporate social responsibility disclosures: Evidence from an emerging economy. Journal of Business Ethics 114(2): 207-223.

Knudsen JS, Moon J, Slager R. 2015. Government policies for corporate social responsibility in Europe: A comparative analysis of institutionalisation. Policy \& Politics 43(1): 81-99.

KPMG (2013). The KPMG Survey of Corporate Responsibility Reporting 2013 (KPMG International).

KPMG (2015). The KPMG Survey of Corporate Responsibility Reporting 2015 (KPMG International).

Kuasirikun N, Sherer M. 2004. Corporate social accounting disclosure in Thailand. Accounting, Auditing \& Accountability Journal 17(4): 629-660.

Levy DL, Kolk A. 2002. Strategic responses to global climate change: conflicting pressures on multinationals in the oil industry. Business and Politics 4(3): 275-300.

Lu JY, Castka P. 2009. Corporate social responsibility in Malaysia - experts' views and perspectives. Corporate Social Responsibility \& Environmental Management 16(3): 146154.

Lund-Thomsen P, Lindgreen A, Vanhamme J. 2016. Industrial clusters and corporate social responsibility in developing countries: what we know, what we do not know, and what we need to know. Journal of Business Ethics 133(1): 9-24.

Mahadeo JD, Oogarah-Hanuman V, Soobaroyen T. 2011a. A longitudinal study of corporate social disclosures in a developing economy. Journal of Business Ethics 104(4): 545-558.

Mahadeo JD, Oogarah-Hanuman V, Soobaroyen T. 2011b. Changes in social and environmental reporting practices in an emerging economy (2004-2007): Exploring the relevance of stakeholder and legitimacy theories. Accounting Forum 35(3): 158-175. 
Marquis C, Glynn MA, Davis GF. 2007. Community isomorphism and corporate social action. Academy of Management Review 32(3): 925-945.

Marquis C, Qian C. 2014. Corporate social responsibility reporting in China: Symbol or substance? Organization Science 25(1): 127-148.

Matten D, Moon J. 2008. "Implicit" and "explicit" CSR: A conceptual framework for a comparative understanding of corporate social responsibility. Academy of Management Review 33(2): 404-424.

McKinsey and Company. 2004. Assessing the Global Compact's Impact. www.wbcsd.ch/web/projects/advocacy/imp_ass.pdf [12 December 2006].

Md ZA, Ibrahim S. 2002. Executive and management attitudes towards corporate social responsibility in Malaysia. Corporate Governance: The International Journal of Effective Board Performance 2(4): 10-16.

Mena S, Palazzo G. 2012. Input and output legitimacy of multi-stakeholder initiatives. Business Ethics Quarterly 22(3): 527-556.

Milne MJ, Adler RW. 1999. Exploring the reliability of social and environmental disclosures content analysis. Accounting, Auditing \& Accountability Journal 12(2): 237-256.

Mitchell CG, Hill T. 2009. Corporate social and environmental reporting and the impact of internal environmental policy in South Africa. Corporate Social Responsibility and Environmental Management 16(1): 48-60.

Momin MA, Parker LD. 2013. Motivations for corporate social responsibility reporting by MNC subsidiaries in an emerging country: The case of Bangladesh. The British Accounting Review 45(3): 215-228.

Monteiro SMdS, Aibar-Guzmán B. 2010. Determinants of environmental disclosure in the annual reports of large companies operating in Portugal. Corporate Social Responsibility \& Environmental Management 17(4): 185-204.

Morhardt JE. 2009. Corporate social responsibility and sustainability reporting on the internet. Business Strategy and the Environment 19(7): 436-452.

Muthuri JN, Gilbert V. 2011. An institutional analysis of corporate social responsibility in Kenya. Journal of Business Ethics 98(3): 467-483.

Neu D, Warsame H, Pedwell K. 1998. Managing public impressions: Environmental disclosures in annual reports. Accounting, Organizations \& Society 23(3): 265-282.

Nikolaeva R, Bicho M. 2011. The role of institutional and reputational factors in the voluntary adoption of corporate social responsibility reporting standards. Journal of the Academy of Marketing Science 39(1): 136-157.

O’Dwyer B. 2002. Managerial perceptions of corporate social disclosure: An Irish story. Accounting, Auditing \& Accountability Journal 15(3): 406-436.

Oh W, Chang Y, Martynov A. 2011. The effect of ownership structure on corporate social responsibility: Empirical evidence from Korea. Journal of Business Ethics 104(2): 283297.

Örtenblad A. 2016. Research Handbook on Corporate Social Responsibility in Context, Cheltenham, UK and Northhampton, MA, USA: Edward Elgar Publishing. 
Owen D. 2008. Chronicles of wasted time? A personal reflection on the current state of, and future prospects for, social and environmental accounting research. Accounting, Auditing \& Accountability Journal 21(2): 240-267.

Parker LD. 2005. Social and environmental accountability research: A view from the commentary box. Accounting, Auditing \& Accountability Journal 18(6): 842-860.

Patten DM. 1991. Exposure, legitimacy, and social disclosure. Journal of Accounting and Public Policy 10(4): 297-308.

Perez-Batres L, Miller VV, Pisani MJ, Henriques I, Renau-Sepulveda J. 2012. Why do firms engage in national sustainability programs and transparent sustainability reporting? Management International Review 52(1): 107-136.

Perry M, Teng TS. 1999. An overview of trends related to environmental reporting in Singapore. Environmental Management and Health 10(5): 310-320.

Potoski M, Prakash A. 2005. Covenants with weak swords: ISO 14001 and facilities' environmental performance. Journal of Policy Analysis and Management 24(4): 745-769.

Rahaman AS, Lawrence S, Roper J. 2004. Social and environmental reporting at the VRA: Institutionalised legitimacy or legitimation crisis? Critical Perspectives on Accounting 15(1): 35-56.

Ratanajongkol S, Davey H, Low M. 2006. Corporate social reporting in Thailand: The news is all good and increasing. Qualitative Research in Accounting \& Management 3(1): 67-83.

Reverte C. 2009. Determinants of corporate social responsibility disclosure ratings by Spanish listed firms. Journal of Business Ethics 88(2): 351-366.

Reynolds M, Yuthas K. 2008. Moral discourse and corporate social responsibility reporting. Journal of Business Ethics 78(1-2): 47-64.

Roberts RW. 1992. Determinants of corporate social responsibility disclosure: An application of stakeholder theory. Accounting, Organizations \& Society 17(6): 595-612.

Rodrigues LL, Craig R. 2007. Assessing international accounting harmonization using Hegelian dialetic, isomorphism and Foucault, Critical Perspectives on Accounting 18(6): 739-757.

Runhaar H, Lafferty H. 2009. Governing corporate social responsibility: An assessment of the contribution of the UN Global Compact to CSR strategies in the telecommunications industry. Journal of Business Ethics 84(4): 479-495.

Savage AA. 1994. Corporate social disclosure practices in South Africa: A research note. Social and Environmental Accounting 14(1): 2-4.

Scott RW. 2001. Institutions and Organizations (2nd ed). Thousand Oaks, CA: Sage Publications.

Shi Y, Magnan M, Kim J. 2012. Do countries matter for voluntary disclosure? Evidence from cross-listed firms in the US. Journal of International Business Studies 43(2): 143-165.

Singh DR, Ahuja JM. 1983. Corporate social reporting in India. The International Journal of Accounting 18(2): 151-169.

Sobhani FA, Amran A, Zainuddin Y. 2009. Revisiting the practices of corporate social and environmental disclosure in Bangladesh. Corporate Social Responsibility \& Environmental Management 16(3): 167-183. 
Steurer R. 2010. The role of governments in corporate social responsibility: Characterising public policies on CSR in Europe. Policy Sciences 43(1): 49-72.

Sumiani Y, Haslinda Y, Lehman G. 2007. Environmental reporting in a developing country: a case study on status and implementation in Malaysia. Journal of Cleaner Production 15(10): 895-901.

Sun H. 2000. Total quality management, ISO 9000 certification and performance improvement. International Journal of Quality \& Reliability Management 17(2): 168-179.

Tagesson T, Blank V, Broberg P, Collin S. 2009. What explains the extent and content of social and environmental disclosures on corporate websites: A study of social and environmental reporting in Swedish listed corporations? Corporate Social Responsibility \& Environmental Management 16(6): 352-364.

Teoh HY, Thong G. 1984. Another look at corporate social responsibility and reporting: an empirical study in a developing country. Accounting, Organizations and Society 9(2): 189206.

Thompson P, Zakaria Z. 2004. Corporate social responsibility reporting in Malaysia. Journal of Corporate Citizenship 13(1): 125-136.

Thorne L, Mahoney LS, Manetti G. 2014. Motivations for issuing standalone CSR reports: A survey of Canadian firms. Accounting, Auditing \& Accountability Journal 27(4): 686-714.

Tilt CA. 1994. The influence of external pressure groups on corporate social disclosure: some empirical evidence. Accounting, Auditing \& Accountability Journal 7(4): 47-72.

Toms JS. 2002. Firm resources, quality signals and the determinants of corporate environmental reputation: Some UK evidence. British Accounting Review 34(3): 257-282.

Tschopp D. Huefner RJ. 2015. Comparing the Evolution of CSR Reporting to that of Financial Reporting. Journal of Business Ethics 127(3): 565-577.

Visser W, Tolhurst N. 2010. The world guide to CSR: a country-by country analysis of corporate sustainability and responsibility. Sheffield: Greenleaf Publishing.

Vuontisjärvi T. 2006. Corporate social reporting in the European context and human resource disclosures: An analysis of Finnish companies. Journal of Business Ethics 69(4): 331-354.

Waddock S. 2008. Building a new institutional infrastructure for corporate responsibility. The Academy of Management Perspectives 22(3): 87-108.

Wanderley L, Lucian R, Farache F, Sousa-Filho J. 2008. CSR information disclosure on the web: A context-based approach analysing the influence of country of origin and industry sector. Journal of Business Ethics 82(2): 369-378.

Westlund R. 2008. Corporate social responsibility. Institutional Investor-International Edition 33(3): $1-4$.

Williams SM. 1999. Voluntary environmental and social accounting disclosure practices in the Asia-Pacific region: An international empirical test of political economy theory. The International Journal of Accounting 34(2): 209-238.

Wilmshurst TD, Frost GR. 2000. Corporate environmental reporting: A test of legitimacy theory. Accounting, Auditing \& Accountability Journal 13(1): 10-26.

WWF. 2013a. More about WWF. http://www.wwf.org.uk/what_we_do/about_us/more_about_wwf/ [05 January 2013]. 
WWF. 2013b. Corporate engagement and corporate partnership. http://www.wwfpak.org/corporate_engagement/corporate_partnerships.php [05 January 2013].

Zeghal D, Ahmed SA. 1990. Comparison of social responsibility information disclosure media used by Canadian firms. Accounting, Auditing \& Accountability Journal 3(1): 38-53.

Zelli F, van Asselt H. 2013. The Institutional Fragmentation of Global Environmental Governance: Causes, Consequences, and Responses. Global Environmental Politics 13(3): $1-13$

Zulkifi N, Amran A. 2006. Realising corporate social responsibility in Malaysia: A view from the accounting profession. Journal of Corporate Citizenship 24(1): 101-114. 
Table 1: The Study Sample, by Industry

\section{Description}

Manufacturing Firms: Manufacture of textiles, chemicals, foods, nonmetallic minerals, electrical equipment, motor vehicles, trailers and semitrailers, refined petroleum products, basic metals, papers, pharmaceuticals, tobacco, and rubber and plastics products

Financial and Insurance Firms: Banks, insurance, and Modarba companies

Other firms: Companies involved in supplying electricity, gas, steam and air conditioning and companies involved in transportation and storage, extraction of crude petroleum and natural gas, telecommunications, and construction of buildings
Number of companies

$67(55.83 \%)$

$40(33.33 \%)$

$13(10.83 \%)$

Total Firms

$120(100 \%)$

Table 2: The Ranking System of a CSR disclosure theme

\begin{tabular}{cl}
\hline Ranks/Score & \multicolumn{1}{c}{ Explanation } \\
\hline 0 & Non-disclosure of information about a theme \\
1 & Vision/goals information disclosure about a theme \\
2 & Information related to management approach \\
3 & Information related to vision/goals + management approach \\
4 & Information related to performance indicators \\
5 & Information related to vision/goals + performance indicators \\
6 & Information related to management approach + performance indicators \\
7 & Information related to vision/goals + management approach + performance \\
\hline
\end{tabular}


Table 3: Descriptive Statistics for the independent and dependent variables and Test of Normality

\begin{tabular}{|c|c|c|}
\hline Descriptive Statistic & & Test for Normality \\
\hline CSR Disclosure Quality Score & & Kolmogorov-Smirnov ${ }^{\mathrm{a}}$ \\
\hline Mean & 15.95 & Statistic $=.190$, df 120, sig. $=.000$ \\
\hline Min & 0 & $\begin{array}{c}\text { van der Waerden's Normal Score } \\
\text { Transformation }\end{array}$ \\
\hline $\operatorname{Max}$ & 88 & Statistic $=.053$, df 120, sig. $=.200^{*}$ \\
\hline Standard Deviation & 18.33 & Approximately Normal \\
\hline Company Size (Total Asset) & & Kolmogorov-Smirnov $^{\mathrm{a}}$ \\
\hline Mean & $\begin{array}{l}36296792 . \\
\quad 55\end{array}$ & Statistic $=.382$, df 120, sig. $=.000$ \\
\hline Min & 11263 & Natural Log Transformation \\
\hline Max & $\begin{array}{l}11534801 \\
00\end{array}$ & Statistic $=.056$, df 120, sig. $=.200^{*}$ \\
\hline Standard Deviation & $\begin{array}{l}12086504 \\
5\end{array}$ & Approximately Normal \\
\hline Company Profitability (ROA) & & Kolmogorov-Smirnov ${ }^{\mathrm{a}}$ \\
\hline Mean & 3.1108 & Statistic $=.182$, df 120, sig. $=.000$ \\
\hline Min & $-45.25 \%$ & $\begin{array}{c}\text { van der Waerden's Normal Score } \\
\text { Transformation }\end{array}$ \\
\hline Max & $44.25 \%$ & Statistic $=.009$, df 120, sig. $=.200^{*}$ \\
\hline Standard Deviation & 12.08562 & Approximately Normal \\
\hline
\end{tabular}

CSR Forums and Networks

membership

Yes

$15.0 \%$

No

$85 \%$

NGOs (WWF) membership

Yes

$16.7 \%$ 
No

$83.3 \%$

CSR standard setting institutions

Yes

$50.8 \%$

No

$49.2 \%$

Environmental Sensitivity

Yes

$35 \%$

No

$65 \%$

$\mathrm{N}=120, *$. This is a lower bound of the true significance. a. Lilliefors Significance Correction 
Table 4: Correlation matrix: CSR disclosure quality and independent variables

\begin{tabular}{|c|c|c|c|c|c|c|c|c|}
\hline $\begin{array}{l}\text { Correlati } \\
\text { ons }\end{array}$ & & $\begin{array}{r}\text { NCSRD } \\
\text { Q1 }\end{array}$ & $\begin{array}{c}\text { CSR } \\
\text { forums } \\
\text { and } \\
\text { network } \\
\text { s } \\
\text { member } \\
\text { ship }\end{array}$ & $\begin{array}{l}\text { NGOs } \\
\text { (WWF) } \\
\text { member } \\
\text { ship }\end{array}$ & $\begin{array}{l}\text { CSR } \\
\text { standar } \\
\text { d } \\
\text { setting } \\
\text { institut } \\
\text { ions }\end{array}$ & $\ln C S$ & $\begin{array}{l}\text { NR } \\
\text { OA }\end{array}$ & $\begin{array}{c}\text { Enviro } \\
\text { n- } \\
\text { mental } \\
\text { sensiti } \\
\text { vity }\end{array}$ \\
\hline \multirow[t]{2}{*}{$\begin{array}{l}\text { NCSRD } \\
\text { Q1 }\end{array}$} & $\begin{array}{l}\text { Pearso } \\
\mathrm{n} \\
\text { Correla } \\
\text { tion }\end{array}$ & 1 & & & & & & \\
\hline & $\begin{array}{l}\text { Spear } \\
\text { man's } \\
\text { rho }\end{array}$ & & & & & & & \\
\hline \multirow{2}{*}{$\begin{array}{l}\text { CSR } \\
\text { forums } \\
\text { and } \\
\text { network } \\
\text { s } \\
\text { member } \\
\text { ship }\end{array}$} & $\begin{array}{l}\text { Pearso } \\
\mathrm{n} \\
\text { Correla } \\
\text { tion }\end{array}$ & $.557^{* *}$ & 1 & & & & & \\
\hline & $\begin{array}{l}\text { Spear } \\
\text { man's } \\
\text { rho }\end{array}$ & $.540^{* *}$ & & & & & & \\
\hline \multirow{2}{*}{$\begin{array}{l}\text { NGOs } \\
\text { (WWF) } \\
\text { member } \\
\text { ship }\end{array}$} & $\begin{array}{l}\text { Pearso } \\
\mathrm{n} \\
\text { Correla } \\
\text { tion }\end{array}$ & $.368^{* *}$ & $.438^{* *}$ & 1 & & & & \\
\hline & $\begin{array}{l}\text { Spear } \\
\text { man's } \\
\text { rho }\end{array}$ & $.357^{* *}$ & $.438^{* *}$ & & & & & \\
\hline \multirow{2}{*}{$\begin{array}{l}\text { CSR } \\
\text { standard } \\
\text { setting } \\
\text { institutio } \\
\text { ns }\end{array}$} & $\begin{array}{l}\text { Pearso } \\
\mathrm{n} \\
\text { Correla } \\
\text { tion }\end{array}$ & $.443^{* *}$ & $.320^{* *}$ & .171 & 1 & & & \\
\hline & $\begin{array}{l}\text { Spear } \\
\text { man's } \\
\text { rho }\end{array}$ & $.476^{* * *}$ & $.320^{* *}$ & .171 & & & & \\
\hline \multirow[t]{2}{*}{$\operatorname{lnCS}$} & $\begin{array}{l}\text { Pearso } \\
\mathrm{n} \\
\text { Correla } \\
\text { tion }\end{array}$ & $.429^{* *}$ & $.246^{* *}$ & .116 & $.245^{* *}$ & \multirow[t]{2}{*}{1} & & \\
\hline & $\begin{array}{l}\text { Spear } \\
\text { man's } \\
\text { rho }\end{array}$ & $.455^{* *}$ & $.267^{* *}$ & .128 & $.305^{* *}$ & & & \\
\hline NROA & $\begin{array}{l}\text { Pearso } \\
n\end{array}$ & $.211^{*}$ & .116 & .134 & $.242^{* *}$ & -.059 & 1 & \\
\hline
\end{tabular}




\begin{tabular}{|c|c|c|c|c|c|c|c|c|}
\hline & $\begin{array}{l}\text { Correla } \\
\text { tion }\end{array}$ & & & & & & & \\
\hline & $\begin{array}{l}\text { Spear } \\
\text { man's } \\
\text { rho }\end{array}$ & $.182^{*}$ & .121 & .135 & $.255^{* *}$ & -.102 & & \\
\hline \multirow{2}{*}{$\begin{array}{l}\text { Environ } \\
\text { mental } \\
\text { sensitivi } \\
\text { ty }\end{array}$} & $\begin{array}{l}\text { Pearso } \\
\mathrm{n} \\
\text { Correla } \\
\text { tion }\end{array}$ & $.423^{* *}$ & $.377^{* *}$ & .141 & $.442^{* *}$ & .170 & .115 & \multirow{2}{*}{1} \\
\hline & $\begin{array}{l}\text { Spear } \\
\text { man's } \\
\text { rho }\end{array}$ & $.435^{* *}$ & $.377^{* *}$ & .141 & $.442^{* * *}$ & $.210^{*}$ & .112 & \\
\hline
\end{tabular}

$\mathrm{N}=120, \operatorname{lnCS}=$ Natural $\log$ of Company Size, NROA = Normal Score of ROA, NCSRDQ1 $=$ Normal Score of CSR Disclosure Quality, ** Correlation is significant at the 0.01 level (2tailed). * Correlation is significant at the 0.05 level (2-tailed). 
Table 5: Determinants of quality of CSR disclosure

\begin{tabular}{|c|c|c|c|c|c|}
\hline & \multicolumn{4}{|c|}{ CSR Disclosure Quality } & \multirow[b]{2}{*}{ Decision } \\
\hline & Prediction & $\begin{array}{c}\text { Model } 1 \\
\text { Control } \\
\text { Model }\end{array}$ & $\begin{array}{c}\text { Model } 2 \\
\text { Experimenta } \\
\text { I Model }\end{array}$ & $\begin{array}{c}\text { Model } 3 \\
\text { Full } \\
\text { Model }\end{array}$ & \\
\hline \multicolumn{6}{|c|}{ CSR Promoting Institutions } \\
\hline $\begin{array}{l}\text { CSR Forums and } \\
\text { Networks membership }\end{array}$ & $+\mathrm{Ve}$ & & $\begin{array}{l}.402 * * * * \\
(.220)\end{array}$ & $\begin{array}{c}.305^{* * * *} \\
(.215)\end{array}$ & Accepted \\
\hline $\begin{array}{l}\text { NGOs (WWF) } \\
\text { membership }\end{array}$ & $+\mathrm{Ve}$ & & $\begin{array}{l}.142 * \\
(.203)\end{array}$ & $\begin{array}{l}.137 * \\
(.189)\end{array}$ & Accepted \\
\hline $\begin{array}{l}\text { CSR standard setting } \\
\text { institutions }\end{array}$ & $+\mathrm{Ve}$ & & $\begin{array}{c}.290 * * * * \\
(.143)\end{array}$ & $\begin{array}{l}.154 * \\
(.149)\end{array}$ & Accepted \\
\hline \multicolumn{6}{|l|}{ Control Variables } \\
\hline $\operatorname{lnCS}$ & $+\mathrm{Ve}$ & $\begin{array}{c}.384 * * * * \\
(.039)\end{array}$ & & $\begin{array}{c}.280 * * * * \\
(.036)\end{array}$ & \\
\hline NROA & $+\mathrm{Ve}$ & $\begin{array}{l}.195 * * \\
(.074)\end{array}$ & & $\begin{array}{l}.118^{*} \\
(.068)\end{array}$ & \\
\hline $\begin{array}{l}\text { Environmental } \\
\text { Sensitivity }\end{array}$ & $+\mathrm{Ve}$ & $\begin{array}{c}.335^{* * * * *} \\
(.152)\end{array}$ & & $\begin{array}{l}.159 * * \\
(.153)\end{array}$ & \\
\hline (Constant) & & $\begin{array}{c}-3.279 * * * * \\
(.605)\end{array}$ & $\begin{array}{c}-.491 * * * * \\
(.099)\end{array}$ & $\begin{array}{c}- \\
2.662 * * * * \\
(.548)\end{array}$ & \\
\hline F-Value & & 20.571 & 26.259 & 18.900 & \\
\hline Significance Value & & 0.000 & 0.000 & 0.000 & \\
\hline Adjusted R Square & & $33.0 \%$ & $38.9 \%$ & $47.4 \%$ & \\
\hline Tolerance & & $\begin{array}{c}0.965- \\
0.980\end{array}$ & $0.746-.897$ & $\begin{array}{c}0.674- \\
.915\end{array}$ & \\
\hline
\end{tabular}


Durbin-Watson

1.839

1.894

1.784

Standardized Beta for Regression Coefficient, Standard errors are parentheses, $\operatorname{lnCS}=$ Natural $\log$ of Company Size, NROA = Normal Score of ROA, NCSRDQ1 = Normal Score of CSR Disclosure Quality, $* \mathrm{P}<0.1, * * \mathrm{P}<0.05, * * * \mathrm{P}<0.01, * * * * \mathrm{P}<0.001$ 


\section{Figure 1:}

Model of the Relationship between CSR Promoting Institutions and CSR Disclosure

\section{CSR Promoting Institutions}

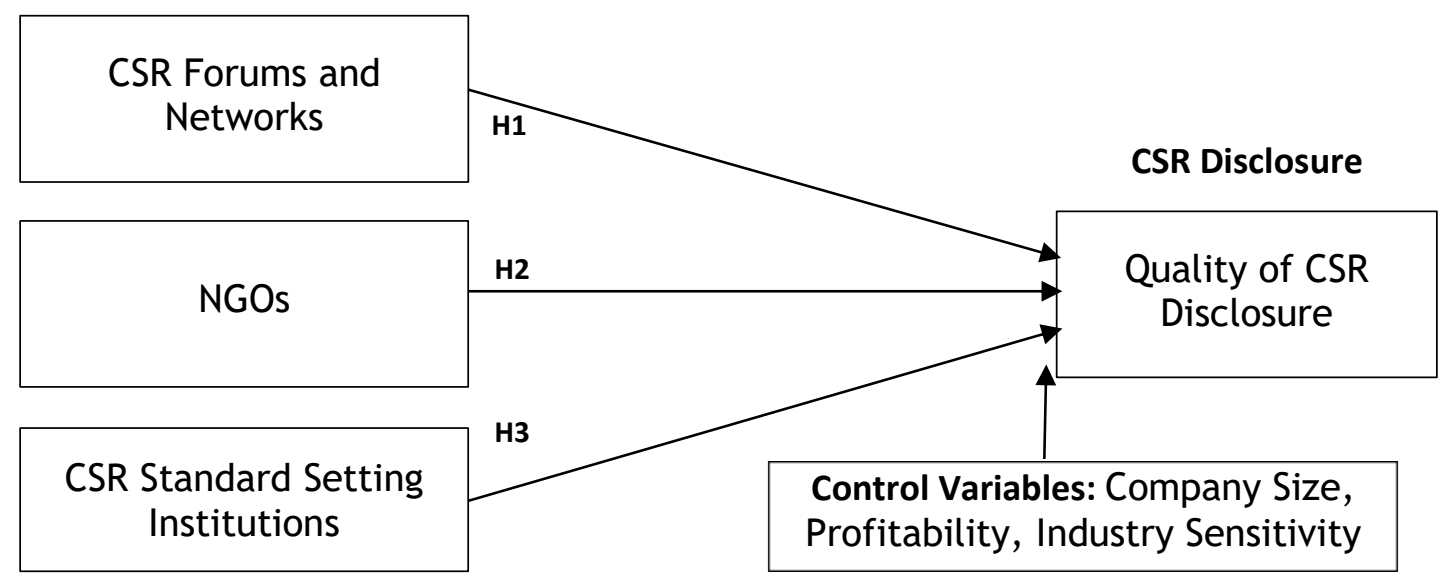

